\title{
Practicing food sovereignty: Spatial analysis of an emergent food system for the Standing Rock Nation
}

\author{
Morgan L. Ruelle, ${ }^{a}$ Stephen J. Morreale, ${ }^{b}$ Karim-Aly S. Kassam ${ }^{c}$
}

Submitted 25 April 2011 / Accepted 28 June 2011 / Published online 13 October 2011

Citation: Ruelle, M. L., Morreale, S. J., \& Kassam, K.-A. S. (2011). Practicing food sovereignty: Spatial analysis of an emergent food system for the Standing Rock Nation. Journal of Agriculture, Food Systems, and Community Development, 2(1), 163-179.

http://dx.doi.org/10.5304/jafscd.2011.021.005

Copyright (C) 2011 by New Leaf Associates, Inc.

\begin{abstract}
Food sovereignty is understood as the right to determine food systems, and the ability to exercise this right requires the capacity to obtain, produce, and distribute culturally relevant foods. In the Standing Rock Nation of the northern Great Plains, efforts to reclaim food sovereignty include projects to increase the availability of gathered and gardened plants that are necessary components of traditional foods. Toward this objective, a voucherbased food assistance program administered by the Standing Rock Tribe is helping elders obtain
\end{abstract}

\footnotetext{
a Department of Natural Resources and American Indian Program, Cornell University, Ithaca, NY 14850 USA; mlr245@,cornell.edu

b Department of Natural Resources, Cornell University, Ithaca, NY 14850 USA; sim11@,cornell.edu

c Department of Natural Resources and American Indian Program, Cornell University, Ithaca, NY 14850 USA; ksk28@,cornell.edu
}

Corresponding author: Morgan L. Ruelle, Department of Natural Resources, Fernow Hall, Cornell University, Ithaca, NY 14853 USA; +1-607-255-9757; mlr245@cornell.edu culturally meaningful foods while contributing to the growth of farmers' markets within the reservation. As program enrollment and market attendance increase, organizers are considering the spatial arrangement of food system components and its influence on accessibility and participation. Our GIS spatial analysis of voucher issuance and redemption patterns reveals that the minimum cost-distance to market explains 33\% of variance in voucher redemption. In order to improve program equity and efficiency, cost-distance models are used to identify potential additional market locations that would reduce the effort associated with trips to market and thus encourage participation. These analyses and possible spatial solutions contribute a powerful tool to improve food-system planning and to enhance the food sovereignty of indigenous communities in rural areas.

\section{Keywords}

cost-distance analysis, farmers' markets, food security, food systems, GIS, indigenous, Lakota/ Dakota, self-determination, Senior Farmers Market Nutrition Program, sociocultural and ecological relations, sovereignty 


\section{Introduction}

Indigenous peoples throughout the world experience the impacts of industrialized food systems on the health of their communities and their habitat. Increasing reliance on industrial food supplies negatively affects human health, local economic opportunities, and the availability of culturally significant foods (Johns \& Sthapit, 2004; Kassam, 2009; Kuhnlein \& Receveur, 1996). In response, many indigenous organizations are working to protect or recover systems that derive healthy and culturally meaningful foods from their landscapes (Kuhnlein, Erasmus, \& Spigelski, 2009). Historically, Native Americans obtained the majority of their food through ecological relations within their landscapes. Colonialism has disrupted those relations by eliminating primary food sources, imposing new land tenure systems, and incentivizing production of commodities that require large-scale regional processing. As a consequence, many Native American communities in the United States cannot exercise cultural choice because contemporary food systems do not provide the foods that they value (LaDuke, 1999).

The international food sovereignty movement developed in response to the trade agreements, state policies, and corporate practices that reinforce the hegemony of global- and industrial-scale food production and distribution systems (Windfuhr \& Jonsén, 2005). The notion of food sovereignty was first articulated by the global coalition of peasants, small farmers, agricultural laborers, and indigenous peoples known as Via Campesina at the 1996 World Food Summit in Rome (Menezes, 2001). Via Campesina defined food sovereignty as the "right of each nation to maintain and develop their own capacity to produce foods that are crucial to national and community food security, respecting cultural diversity and diversity of production methods" (Via Campesina, 1996). In protesting global trade structures, the food sovereignty movement has focused on food sovereignty as a right, but has also revealed its requirement for local capacities. The right to obtain, produce, and distribute food in accordance with community values is irrelevant if communities do not know how to do so. Indigenous food systems are enabled by context-specific ecological knowledge (Kassam, 2009). In addition, knowledge generated through partnerships with research institutions can be used to strengthen and expand culturally appropriate and ecologically sustainable indigenous food systems (Kassam, Soaring Eagle Friendship Centre, 2001; Kassam, The Wainwright Traditional Council, 2001).

The food sovereignty movement is in many ways a reaction to the food security paradigm that has dominated development programs for the past 40 years (Shaw, 2007). Because food is understood as a volume of biochemicals, food security is achieved when people are consuming adequate calories and nutrients (Anderson \& Cook, 1999). By comparison, food sovereignty advocates recognize that food emerges from complex sociocultural and ecological processes (Kassam, 2009). Food as a volume satisfies important metabolic needs, while food as a manifestation of culture and ecology reinforces the vital structure of communities (Kassam \& The Wainwright Traditional Council, 2001). Recent revisions of the food security concept have included considerations of cultural food preferences and ecological sustainability (e.g., FAO, 2006), but still do not recognize the rights of nations and communities to determine their own food systems based on their ecological knowledge and with respect to their core cultural values (Kassam, Karamkhudoeva, Ruelle, \& Baumflek, 2010; United Nations, 2008).

The word "sovereignty" has a complex history of use among Native Americans in the United States (Pevar, 2002). It is therefore important to consider how the multiple meanings of sovereignty may inform understandings of food sovereignty in Native communities. In conversations with elders from the Standing Rock Nation in the northern Great Plains, sovereignty is frequently described as an inherent right to self-determination that is recognized by treaties between the U.S. government and tribal representatives. On the other hand, some elders indicate that sovereignty must be asserted, and therefore requires tribal members to exercise capabilities or demonstrate specific rights. Sovereignty is also sometimes related to self-sufficiency or self-reliance, i.e., an ability to generate what is 
Figure 1. The Standing Rock Nation in the Northern Great Plains of the United States

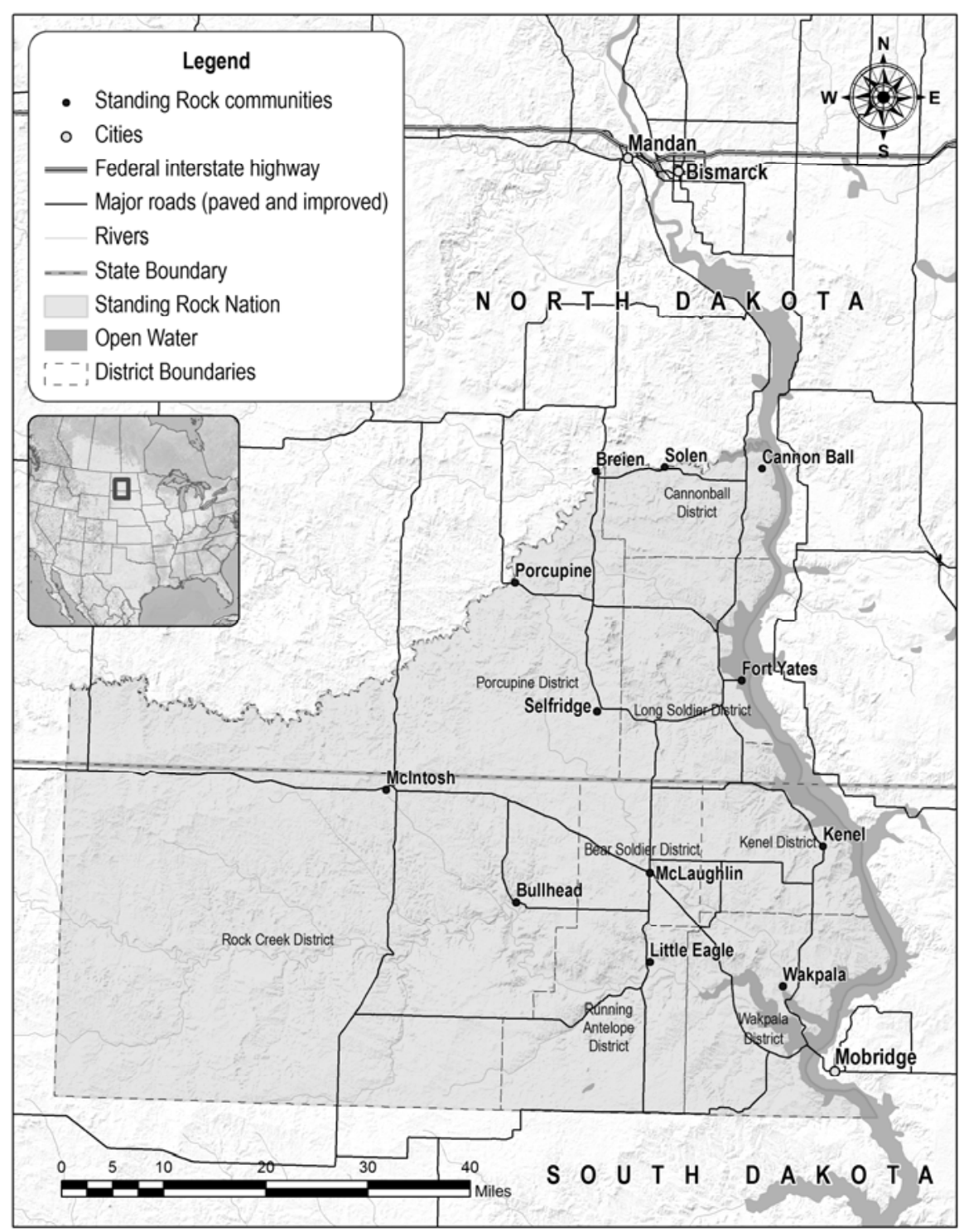

follow, we consider how innovative food assistance mechanisms coupled with the development of new farmers' markets can strengthen food sovereignty for indigenous communities. We combine qualitative research methods with geographic information systems (GIS) to assess the contributions of new markets to food sovereignty. We demonstrate that GIS is more than a technical tool, because it can support and increase local knowledge. In this regard, we add to the growing body of evidence that GIS can empower local organizations and marginalized social groups (Elwood, 2002). Specifically, as local knowledge drives the creation and transformation of sovereign food systems, the use of GIS can inform strategic placement of food system components to improve system equity.

\section{Sociocultural and Ecological Context}

The Standing Rock Nation is located west of the Missouri River where it flows across the border between North necessary for the well-being of the individual, the extended family (thióspaye), the community, or the nation. These complex local understandings of sovereignty have shaped the conceptualization of food sovereignty used in this paper, which highlights the rights and abilities of a person, community, or nation to make choices about their food system.

Applied research in the service of communities can contribute new knowledge to enhance their food sovereignty. In the narrative and analyses that and South Dakota (see figure 1). The reservation encompasses 2.3 million acres $(930,000 \mathrm{ha}$ ). In 2009 , the population of Standing Rock was estimated at 8,290, of which 75\% are Native American (U.S. Census Bureau, 2009a; 2009b). Most Native Americans living in Standing Rock are enrolled in the Standing Rock Sioux Tribe, which includes Dakota- and Lakota-speaking cultural groups (Ullrich, 2008). Fort Yates, North Dakota, is the seat of the tribal government, including the offices of the Tribal Chairman and the Tribal Council. The reservation is divided into eight administrative 
districts, each of which elects a representative to the Tribal Council and a district chairperson who oversees district programs. Standing Rock districts own and manage community centers, social services, range and agricultural lands, cattle operations, and bison herds.

Prior to the middle of the nineteenth century, the food sovereignty of Dakota and Lakota people was well established, even though the right to hunt in certain areas was often challenged by other Native groups (Standing Bear, 1975). The ability to hunt, gather, grow, and distribute food required regular adaptations of ecological knowledge in response to environmental change, for example during the Little Ice Age and upon the arrival of Spanish horses. As settlers moved into the Great Plains, Native leaders negotiated a series of treaties with the U.S. government that promised the protection of specific rights within newly delimited territories (Smith, 1981). However, when conflict between Plains tribes and the U.S. government escalated in the 1860s and 1870s, the frontier Army led a systematic campaign to eliminate the bison herds on which tribes throughout the region relied. U.S. military leaders recognized that the political sovereignty of Native groups was strengthened by their ability to feed themselves, and bison were targeted as their primary food supply (Smits, 1994).

Following forced removal of the Dakota and Lakota to reservations, agents from the Office of Indian Affairs required that Standing Rock families adopt European-American farming systems.

Although these agents claimed to promote the selfsufficiency of Native peoples, they worked to replace traditional modes of food production with farming technologies that would prove unreliable in the drought-prone northern Great Plains (Pfaller, 1992). As these farming systems failed to support Native families, reliance on military rations led to widespread dependencies on food assistance programs by the early twentieth century (Jackson, 1994).

Nevertheless, according to elders living today, most Standing Rock families continued to grow, gather, and hunt much of their own food into the 1950s.
Floodplain forests were the primary sources of food, medicine, fuel, and fiber. In 1959, despite the protestations and legal actions of the Standing Rock tribal government, the U.S. Army Corps of Engineers completed the Oahe Dam on the main stem of the Missouri River, which permanently inundated 55,993 acres (22,660 ha) of Standing Rock land and forced the relocations of over 200 families (Kraft, 1990; Lawson, 1994). GIS analysis indicates that these losses represented half of all forests on Standing Rock (Ruelle, 2011). Although some important plants and animals remained in wooded ravines and upper reaches of the Missouri's main tributaries, the Oahe Dam drastically reduced opportunities for families to grow, gather, and hunt the plants and animals that are critical to their food culture, social systems, and physical health.

The continued erosion of food sovereignty has had alarming consequences for the health of Standing Rock communities. A needs assessment conducted by Standing Rock Nutrition for the Elderly and Caregiver Support (NFE) and the Standing Rock Elder Advisory Council confirmed that Standing Rock elders (those aged 60 and older) are suffering from high rates of diet-related diseases (NFE, 2007). For example, the incidence of Type II diabetes among Standing Rock elders is twice the national average ( $46 \%$ as compared to $23 \%$; CDC, 2007). Despite the prevalence of diet-related diseases, interviews reveal that most elders do not follow diets prescribed by their doctors. Elders often stated that the recommended foods are unfamiliar or the dietary restrictions are culturally inappropriate. Many elders say that consuming traditional foods would improve their health, but report that their consumption of those foods has declined. Seventy-one percent of elders say they know how to gather plants they need to prepare traditional foods (NFE, 2007), but many are physically not able to do so. Elders' ecological knowledge is a vital asset on Standing Rock, and some are teaching younger people to gather and use non-cultivated plants from their landscape (Ruelle \& Kassam, 2011). 
The lack of local distribution systems for culturally meaningful and ecologically sustainable foods is an impediment to the restoration of food sovereignty. Although the Standing Rock landscape is home to a diversity of plant and animal foods, only a small percent is distributed to local markets where it is available to elders. Instead, crops and livestock raised in Standing Rock are delivered to local storage facilities from which they are sold into regional and national distribution networks; Standing Rock residents rely on grocery and convenience stores that market food from the same networks. In 2009, small grocery stores were located in Fort Yates, McLaughlin, and McIntosh; convenience stores were located in Fort Yates, McLaughlin, Cannon Ball, Selfridge, and Bullhead (see figure 1). Some of these stores sell a small volume of locally grown vegetables during gardening seasons, but the majority of fresh fruits and vegetables sold in Standing Rock is grown in other regions of the United States, Canada, and Mexico. Many elders therefore lack access to the locally grown and gathered foods that they need to prepare traditional foods.

With the principal objective of expanding access to these healthy and culturally significant foods, NFE applied to the USDA Food and Nutrition Services to initiate a Senior Farmers Market Nutrition Program (SFMNP) in Standing Rock. SFMNP is a national program administered by state and tribal agencies that provides low-income elders and their spouses with vouchers that can be exchanged for fresh, unprocessed, locally grown fruits, vegetables, and herbs at authorized farmers' markets, roadside stands, and community-supported agriculture operations. In 2008, NFE became the fifth tribal agency in the United States to receive federal funding for an SFMNP. The program administered by NFE allows elders to exchange vouchers for many of the noncultivated plants they use to prepare traditional foods. The inclusion of these plants as eligible foods expands economic opportunities for local gatherers as well as small-scale farmers and gardeners.

In addition to issuing SFMNP vouchers to elders, NFE authorizes farmers' markets and individual vendors to exchange the vouchers for produce. In 2009, NFE authorized 36 vendors operating at four farmers' markets and four roadside stands. At first, the only farmers' market located within Standing Rock was in Fort Yates, North Dakota. NFE collaborated with the Native Gardens Project (NGP) of the Standing Rock Diabetes Program and Sioux County Cooperative Extension (SCCE) to improve and expand this market. The market had opened in 2007, but vendor participation waned in 2008. Market organizers and vendors attributed this decline to a change in organizational leadership and low market attendance because families could not afford the produce. In 2009, organizers anticipated that the new SFMNP vouchers would infuse money into the Standing Rock Farmers Market and increase vendor attendance and profitability.

Although the market in Fort Yates is close to the largest population of elders, NFE and partners envision a food system that increases market access for the other administrative districts. Disparities in access are a concern due to local perceptions that communities located farther from Fort Yates receive fewer services provided by tribal government agencies. In August 2009, NFE observed that voucher redemption rates in the southern districts of Standing Rock had been significantly lower than in districts closer to Fort Yates, and decided to organize an opportunity to exchange vouchers closer to those districts. NFE established a temporary market in McLaughlin, South Dakota, and provided travel funds for a vendor to sell vegetables there for two days in August and October. During those two days, elders exchanged as many vouchers in McLaughlin as they ultimately exchanged at the much larger market in the city of Bismarck over the course of the entire season (see figure 2).

Following these successes, NFE and its partners are looking for ways to strengthen and expand the Standing Rock food system through the SFMNP and other programs. The goal of our research is to contribute to these continued efforts to restore the food sovereignty of Standing Rock. First, based on our observations of market activity and conversa- 
Figure 2. Dollar Value of SFMNP Vouchers Redeemed With Reference to Category of Produce

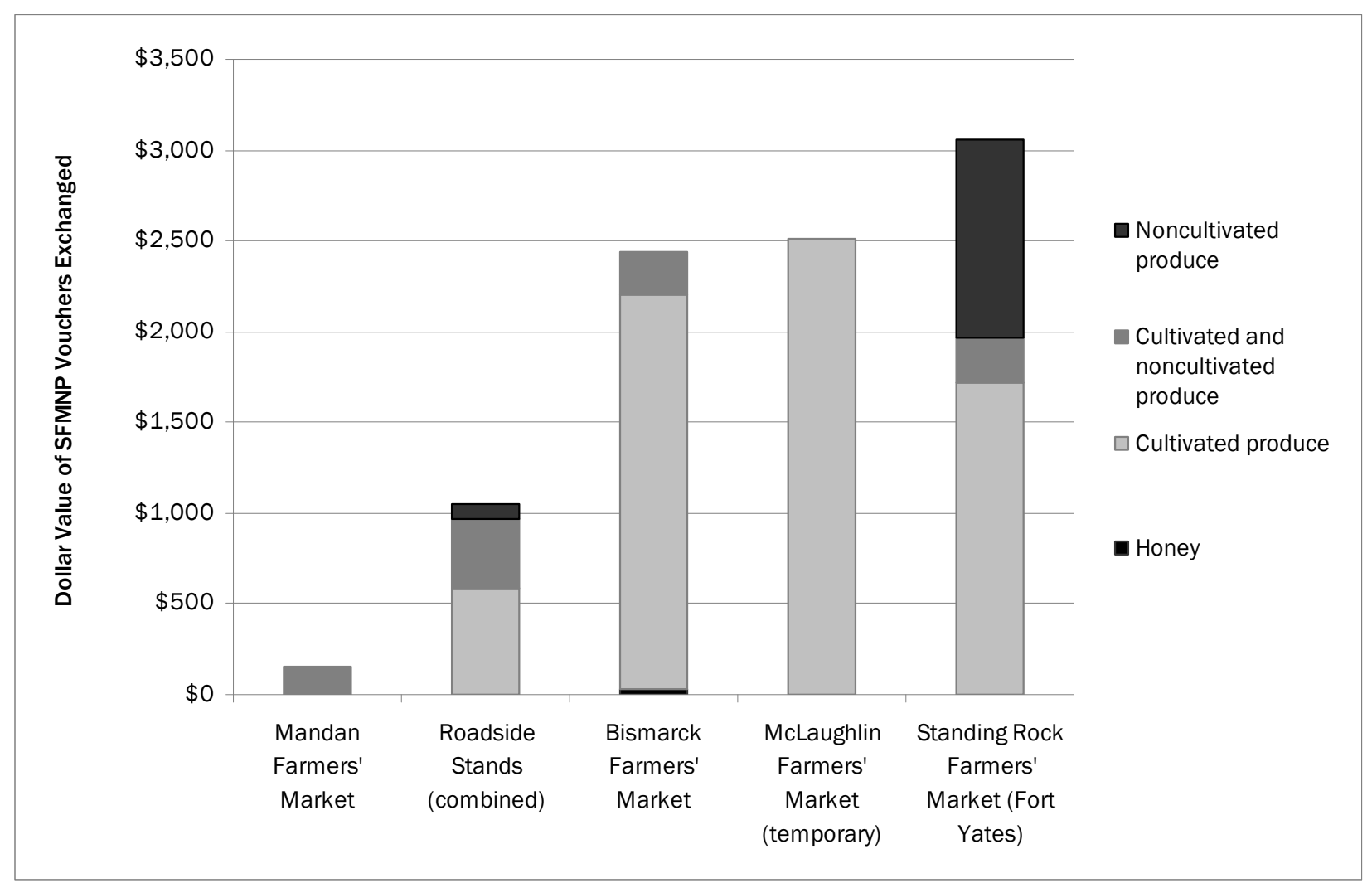

tions with both elders and vendors, we evaluate the contributions of the Standing Rock Farmers Market to food sovereignty. Second, we analyze patterns of SFMNP voucher redemption to determine if costs associated with travel to market affect voucher redemption rates. Third, we compare potential additional market locations and their ability to improve program equity by reducing travel costs for participating elders and vendors. Our broader aim is to develop models that anticipate the success of new farmers markets in rural landscapes where access to fresh, healthy, and culturally significant foods is limited by the lack of local distribution systems.

\section{Applied Research Methods}

From February 2007 to February 2008, the first author served as an Americorps VISTA volunteer in Standing Rock. In partnership with the NFE director and staff, he helped conduct the needs assessment of elders as well as develop the original proposal for the Standing Rock SFMNP. He then returned to Standing Rock in 2009 to assist with voucher program implementation and market development. The data collected during this period are the foundation for the current analyses. Qualitative data about the sociocultural and ecological significance of the Standing Rock Farmers Market were obtained through participant observation, including informal conversations with participating elders and vendors. Quantitative data about voucher issuance and redemption were obtained through a data-sharing agreement with NFE. The names of elders and vendors were replaced with alpha-numeric codes to ensure their anonymity.

SFMNP procedures allow each voucher to be traced from its issuance in a specific district to its redemption at a particular market or roadside stand. Specifically, each voucher is printed with a 6-digit identifier that can be used to determine the district where it was issued. NFE provides each vendor with a stamp that includes a unique vendor number. Whenever a program participant 
exchanges a voucher, the vendor signs, dates, and stamps it before submitting it to NFE for payment. Vendor numbers stamped on each voucher are associated with specific locations because no vendor operates at more than one market or roadside stand. Therefore, the locations of voucher redemptions can be tracked and spatially analyzed in a GIS database.

With the knowledge of origins and end-points of each voucher, it was possible to estimate the distance traveled as well as the cost or difficulty of travel by elders to markets. Cost-distance analysis is a spatial-analytical method for measuring the costs associated with movement across a variable landscape. Frequently used to model movement of plants and animals (e.g., Adriaensen et al., 2004), this method has been employed in previous studies of human access to food (Hallett \& McDermott, 2010). First, a cost-surface grid was generated for the Standing Rock landscape. Each cell in this grid was assigned a value according to the relative difficulty of travel in that cell. Because most elders and vendors drive to markets, cost was modeled relative to travel on paved roads. Cells with gravel roads or without any roads were assigned higher cost values. ${ }^{1}$ Second, the cost-distance tool in Spatial Analyst (ESRI ArcGIS 9.3) was used to produce a series of cost-distance maps. Using the values in the cost-surface grid, the cost-distance tool calculated the minimum cumulative costdistance from all points in the landscape to a specified destination, in this case a farmers' market. Cost-distance maps were generated for each existing and potential market location in order to compare the cost-distances to those locations from districts and communities.

An analysis of independent trips to market was necessary to investigate whether cost-distance to market shaped patterns of voucher redemption. All

\footnotetext{
${ }^{1}$ Cells with paved roads were assigned a value of 1 , cells with gravel roads a value of 1.33 (based on an estimated average speed of 60 miles/hour on paved roads $\div 45$ miles/hour on gravel roads), and cells without roads a value of 30 (based on an average speed of 60 miles/hour on paved roads $\div 2$ miles per hour when traveling by foot).
}

vouchers exchanged by the same household at the same market on the same day were assumed to be redeemed during the same trip. However, because the database was coded for anonymity, the precise starting point of each trip was unknown. The costdistance per trip was therefore calculated as the minimum cost-distance from a district (a polygon) to the market where the voucher was exchanged (a point). ${ }^{2}$ In addition, the minimum cost-distance to any of the existing markets was also calculated for each district. Redemption rates per district were then calculated as the number of vouchers redeemed divided by the total number of vouchers issued for each district.

New maps depicting cost-distances were created to analyze the effects of potential new markets on minimum cost-distance values. These maps were used to assess spatial overlap of cost-distance radii from proximate markets and to provide an effective visual reference for decision-makers. Costdistances from communities to potential new market locations were compared with costdistances to the existing market in Fort Yates and the temporary market in McLaughlin. In addition, counts of eligible persons in each community were obtained from NFE to predict the average minimum cost-distance to any market for all participants following the establishment of new markets. The average minimum cost-distance to market for all participants in all communities $\left(C D_{\text {avg }}\right)$ was calculated as follows:

$$
C D_{\text {avg }}=\frac{\sum_{i=1}^{n}\left(P_{i} \cdot C D_{i}\right)}{\sum_{i=1}^{n} P_{i}}
$$

Where $P_{i}$ is the count of eligible persons in community $i, C D_{i}$ is the minimum cost-distance from community $i$ to any market, and $n$ is the total number of communities in Standing Rock.

To complement the analysis of elders, it was important to consider whether vendors are able to

\footnotetext{
2 This calculation is therefore based on the minimum costdistance from any point within the district polygon to the destination market. This point will always be located on the edge of the polygon. Trips made within the same district were assigned a cost-distance of 0 .
} 
attend markets in terms of their numbers and locations. The locations of authorized and potential vendors were obtained through a data-sharing agreement with NGP. Authorized vendors had already participated in the SFMNP in 2009, whereas those designated as potential vendors had participated in other NGP-supported projects in 2009 and are therefore likely to operate at local markets in the future. The numbers of vendors located less than 20 cost-distance units from each existing and potential market were tabulated for analysis.

\section{Results}

The success of local organizations in promoting food sovereignty can be evaluated in terms of observable changes in the food system that reflect local decision-making processes, as well as increased opportunities for communities to engage and expand their food systems according to their own values, concerns, and knowledge of their habitat. In this regard, the voucher program and the establishment of new farmers' markets are both indicators of and contributions to food sovereignty.

By the end of the 2009 harvest season, 347 individuals from 194 households (representing approximately $71 \%$ of eligible residents) had each received US $\$ 50$ worth of SFMNP vouchers. Thirty-six vendors operating at four farmers' markets and four individual roadside stands were authorized to accept SFMNP vouchers in exchange for fresh local produce. The greatest number of vouchers (18\% of all those issued) was redeemed by vendors at the Standing Rock Farmers Market in Fort Yates. Whereas other markets offered primarily cultivated fruits, vegetables and herbs, at least $36 \%$ of voucher redemptions at the Standing Rock Farmers Market were for noncultivated plants (see figure 2). Noncultivated plants included thinpsinla (prairie turnip, Pediomelum esculentum), buffalo berries (Shepherdia argentea), wild plums (Prunus americana), chokecherries (Prunus virginiana), and sand cherries (Prunus pumila). These five plants are of significant cultural value because they are used to prepare a number of traditional foods.
A farmers' market is an important node within economic networks of supplies and demands, and also in the social-ecological networks through which knowledge is transmitted and transformed. Our observations and conversations at the Standing Rock Farmers Market indicate that the social impacts of voucher exchanges were remarkable. Elders said that their visits to the farmers' market resulted in strengthened and expanded relations with other elders, gatherers, and gardeners. Even after their SFMNP vouchers had been exchanged, elders continued to attend the Standing Rock Farmers Market to observe market activity and to socialize. The market became an important place for elders to connect with their community and share their knowledge about traditional foods.

The market also provided opportunities for vendors to share ecological knowledge with each other. Ethics are an implicit dimension of ecological knowledge, and communities of gatherers affirmed their shared commitments to the conservation of plants. More experienced gatherers emphasized the importance of specific practices to conserve plants, and shared knowledge about how to do so. For example, gatherers spoke about the importance of digging thimpsinla in such a way that the ground is undisturbed and the inflorescence remains upright so that seeds can still disperse. As ecological knowledge moves within social relations at a market, the community learns how to sustain the relations with plants that are critical to food sovereignty.

The Standing Rock SFMNP introduces a relatively small amount of money into the local food economy, but has already provided 14 Standing Rock residents and their families with supplemental income from gardening and gathering. The SFMNP acts as more than just a food assistance program. It relies upon ecological knowledge within communities to access culturally meaningful foods for those who otherwise cannot afford them. As a result, vendors gain skills and confidence in their ability to earn money through gathering and gardening, and local capacity for food sovereignty is further enhanced. 
Conversations with Standing Rock vendors revealed that they are motivated by more than money to gather or grow foods. They describe their work as a service to communities because they provide foods that are often otherwise unavailable. As they interact with their communities during voucher exchanges and cash sales, vendors share significant knowledge about traditional foods and the cultural values they represent. In addition, face-to-face interactions with elders offer vendors insight into the multiple dimensions of demand for food that give their work meaning. Although we should be careful to not downplay vendors' financial objectives, to simplify their motivations to an economic calculus would under- estimate their intellectual, emotional, and spiritual contributions to community well-being.

\section{Cost-distance as a predictor of voucher redemption}

The percent of eligible residents who joined the voucher program was fairly consistent among districts, ranging from $65 \%$ to $86 \%$ (mean $73 \%$ $\pm 6.7 \mathrm{SD}$ ). Despite the relatively even distribution of vouchers, the percent that were redeemed by participants was more variable, ranging from as low as $28 \%$ in Porcupine District to as high as $70 \%$ in Running Antelope District (mean 50\% \pm 12.0 SD). Analysis of trips to redeem vouchers within Standing Rock revealed that residents traveled only the

Figure 3. Cost-distance Per Trip to Market ( $\mathrm{N=277)}$ Made by Voucher Recipients

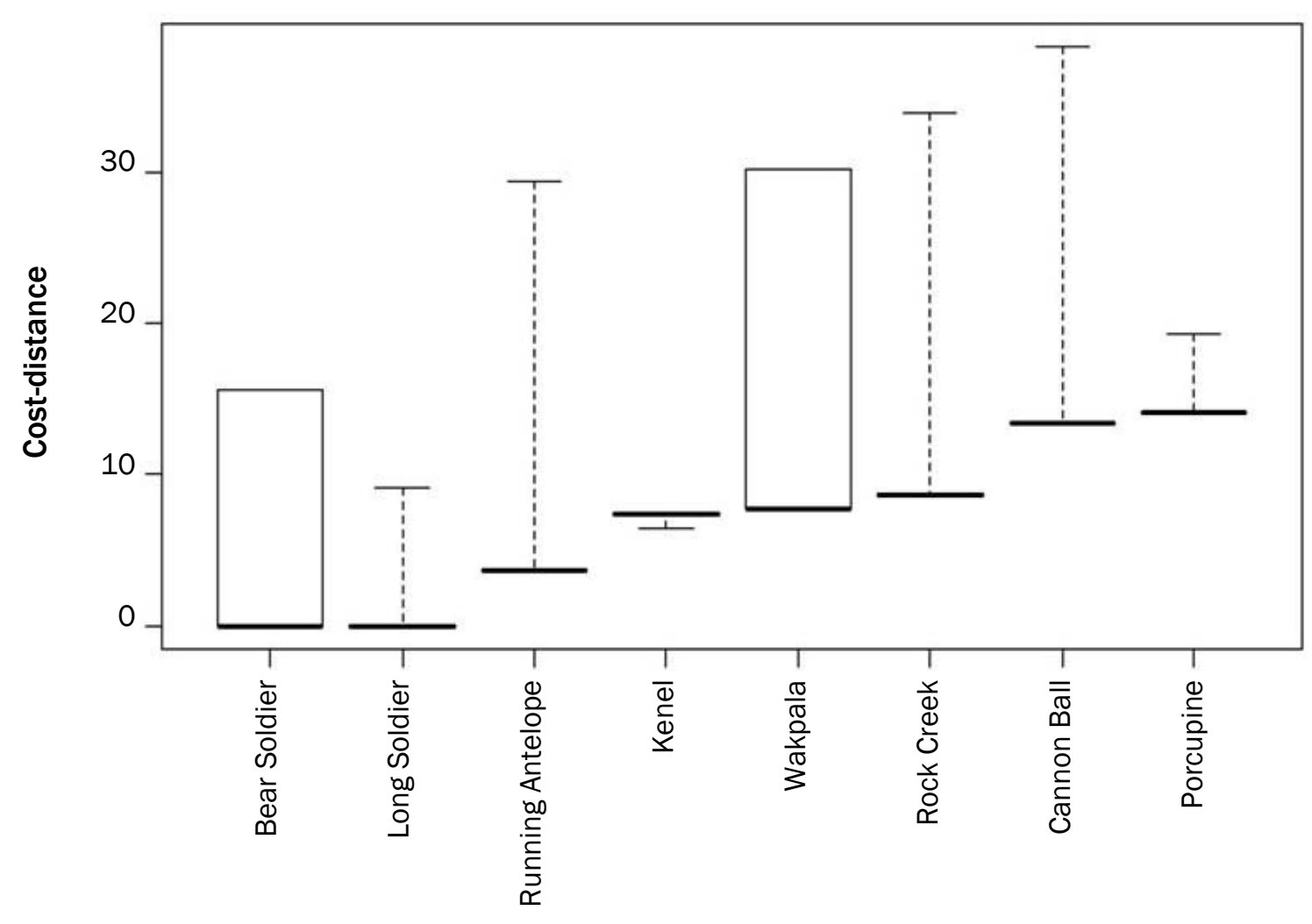

District of Origin

Most trips were made to the minimum cost-distance. Cost-distance is a measure that incorporates the distance and difficulty of travel. In this figure, bars represent medians, boxes represent interquartile ranges, and whiskers represent minimum and maximum cost-distance values for trips. 
minimum cost-distance for the majority of trips (see figure 3). The minimum cost-distance to a market from each of the districts ranges from 0 (Bear Soldier and Long Soldier districts) to 14.2 (Porcupine District). In all but one district the median cost-distance per trip is equal to the minimum cost-distance, indicating that at least $50 \%$ of trips were made to the nearest market.

Comparison of voucher redemption rates among districts confirmed that distance and difficulty of travel are important determinants of program impact (see figure 4). Analysis per district showed that as cost-distances increase, redemption rates decreased. Based on a simple linear regression analysis, cost-distances to the nearest markets explain more than one third of the variance in SFMNP voucher redemption rates between districts $\left(\mathrm{r}^{2}=\right.$ 0.3348, $\mathrm{p}=0.07757)$. Notably, three of the four districts with the highest minimum cost-distance values experienced the lowest redemption rates.
Analysis of potential new market locations

As a means to analyze potential market locations, cost-distance calculations in GIS confirmed that a permanent farmers' market located in McLaughlin would reduce the minimum cost-distance to a market for residents of Bullhead, Little Eagle, McIntosh, Mobridge, and Wakpala, as well as McLaughlin itself, which is currently the second largest population of SFMNP participants. In addition, the 20-mile cost-distance radius illustrated for a McLaughlin market shows relatively little spatial overlap with the same cost-distance radius for the Standing Rock Farmers Market in Fort Yates (see figure 5), indicating complementarity rather than redundancy. Our predictions for success are supported by empirical evidence: the temporary market in McLaughlin resulted in more voucher exchanges during two market days than the much larger market in Bismarck achieved during 106 market days (see figure 2).

Figure 4. Effect of Minimum Cost-Distance to Market on Voucher Redemption Rates

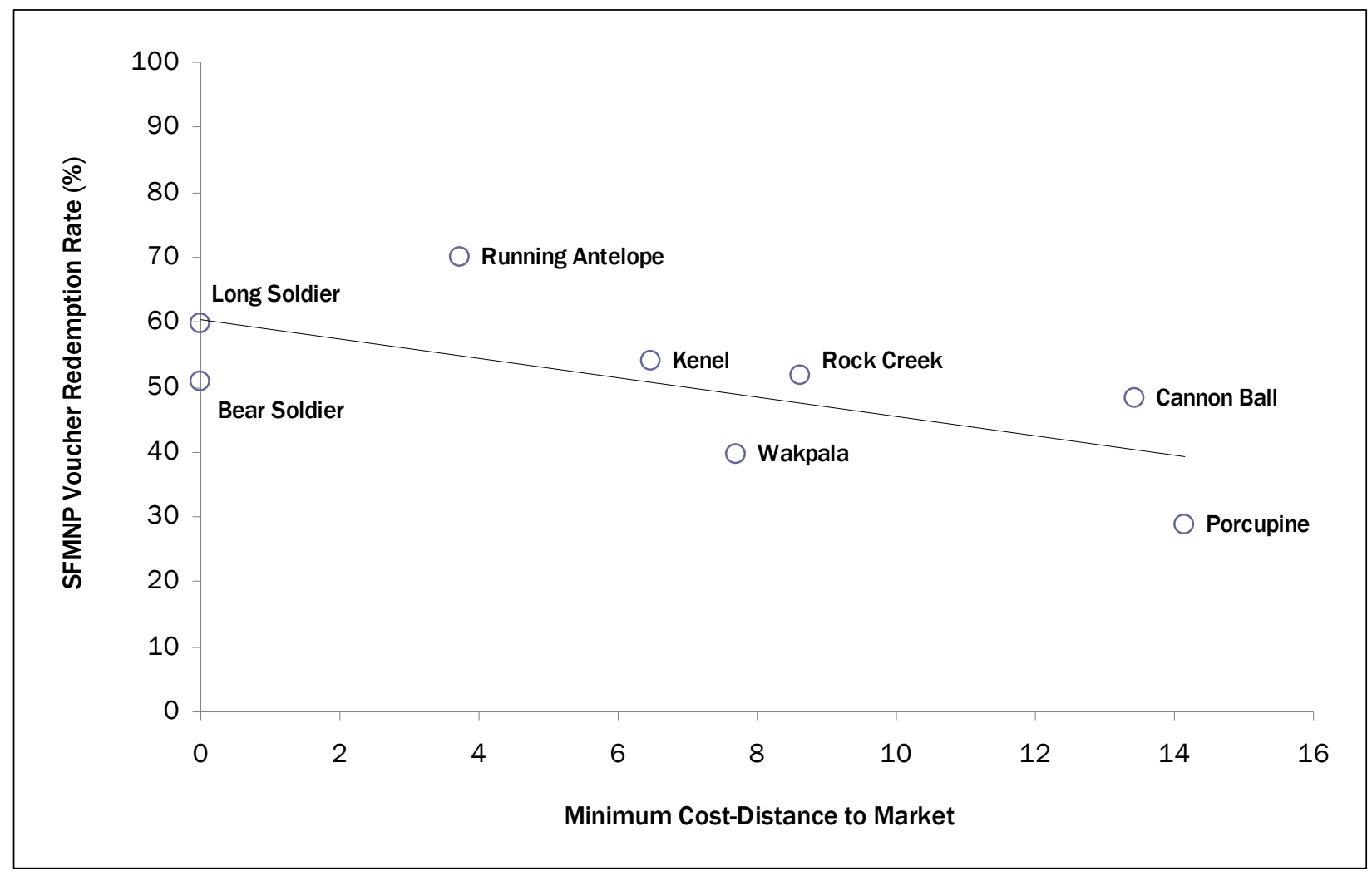


Given the likely success of a market in McLaughlin, further analysis compared potential locations for a third market, assuming that the market in McLaughlin will have been made permanent. Undoubtedly, determining which SFMNP participants have the highest remaining cost or difficulty of travel to market could help organizers address program equity. If organizers are concerned about elders who live farthest from markets and experience the most difficulty traveling to them, they will consider supporting a new market in the communities farthest from Fort Yates and McLaughlin. On the other hand, the population eligible to participate in the SFMNP is low in many of these communities, so the number of participants served would be small. Of the communities that are furthest from Fort Yates and McLaughlin, only Porcupine, Wakpala, and Cannon Ball have more than 10 elders who are eligible for the SFMNP.

Figure 5. Predicted Changes in Average Cost-Distance to Market Following the Addition of New Markets

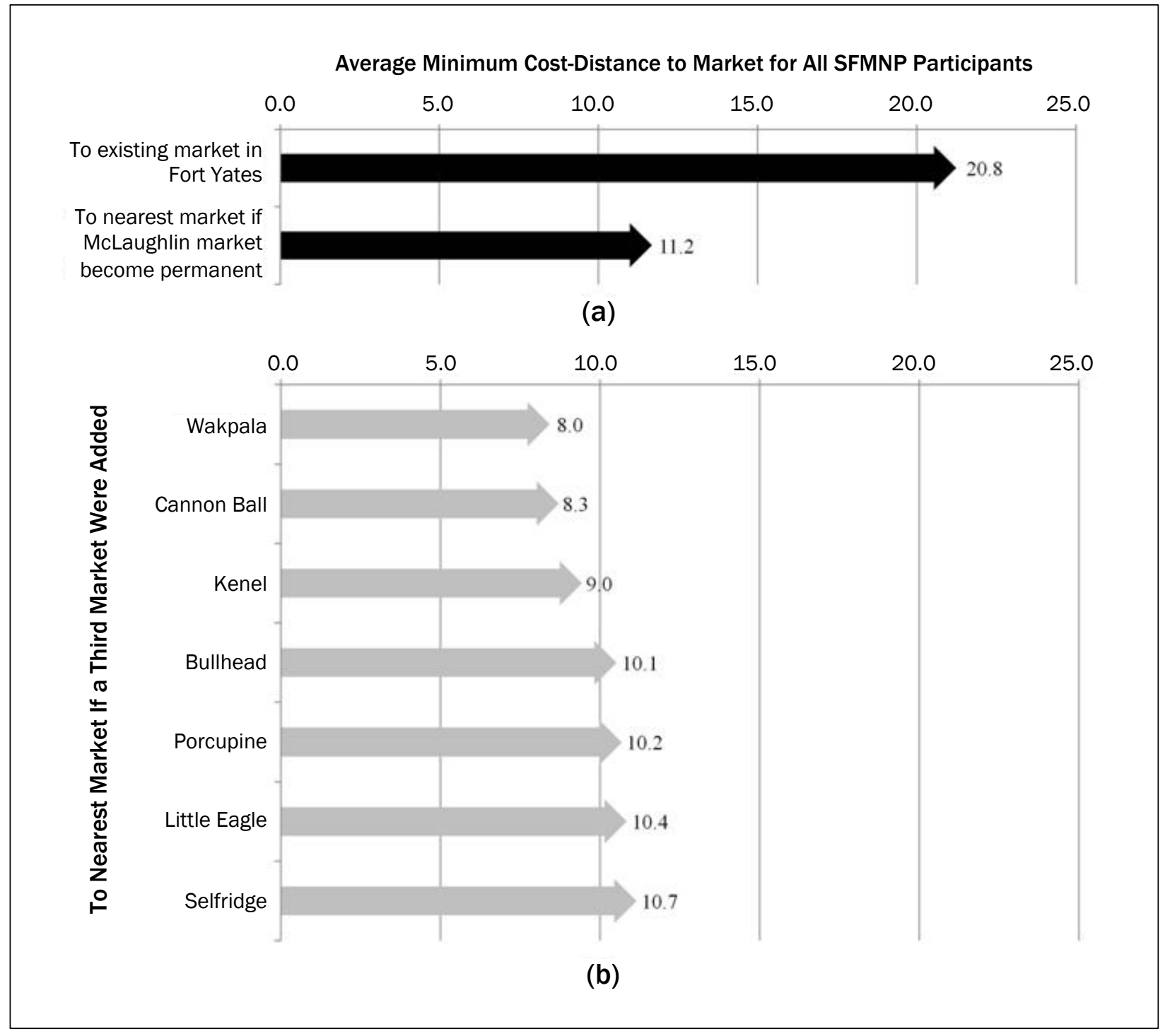

(a) Making the existing market in McLaughlin permanent results in a substantial reduction of average minimum cost-distance. (b) Adding a subsequent third market yields further reductions; as a single third market, Wakpala would reduce the average minimum cost-distance the most. 
A new market in one community can reduce the minimum cost-distances for elders traveling from other communities. Therefore, in order to locate a market that would improve the food system for the most elders, it is important to account for the number of eligible elders in each community as well as the distance and difficulty of travel to new markets from all other communities. Based on the number of elders in each community, the average minimum cost-distance to market for all participants in all communities was calculated to examine the effects of new markets (see figure 5). Presently, the average minimum cost-distance for all participants to the market in Fort Yates is 20.8, and a permanent market in McLaughlin is predicted to reduce that figure by $46 \%$ (see figure 5a). Assuming the temporary market in McLaughlin becomes permanent, we compared average minimum costdistance to market for all participants if a subsequent third market were established in any other community (see figure $5 b$ ). Using these straightforward spatial tools, we calculated that the greatest changes in average minimum cost-distance for all participants are predicted to result from a new market in either Wakpala or Cannon Ball. These reductions are less than those achieved by the market in McLaughlin, but either market would increase market accessibility for multiple remote communities (see figure 6). Unfortunately, neither of these markets would reduce the costdistance to market for elders in Porcupine, so the low voucher redemption rates in that community are not predicted to improve as a result of those new markets.

For vendors, analysis of cost-distances showed that individuals who were authorized to accept SFMNP vouchers at the Standing Rock Farmers Market live at cost-distance radius values between 0 and 42 from that market (mean $=18 \pm 14.9$ SD). Six authorized vendors and 31
Figure 6. Comparison of Changes in Cost-Distances to Market with the Addition of Markets in (a) Porcupine, (b) Wakpaka, and (c) Cannon Ball Communities

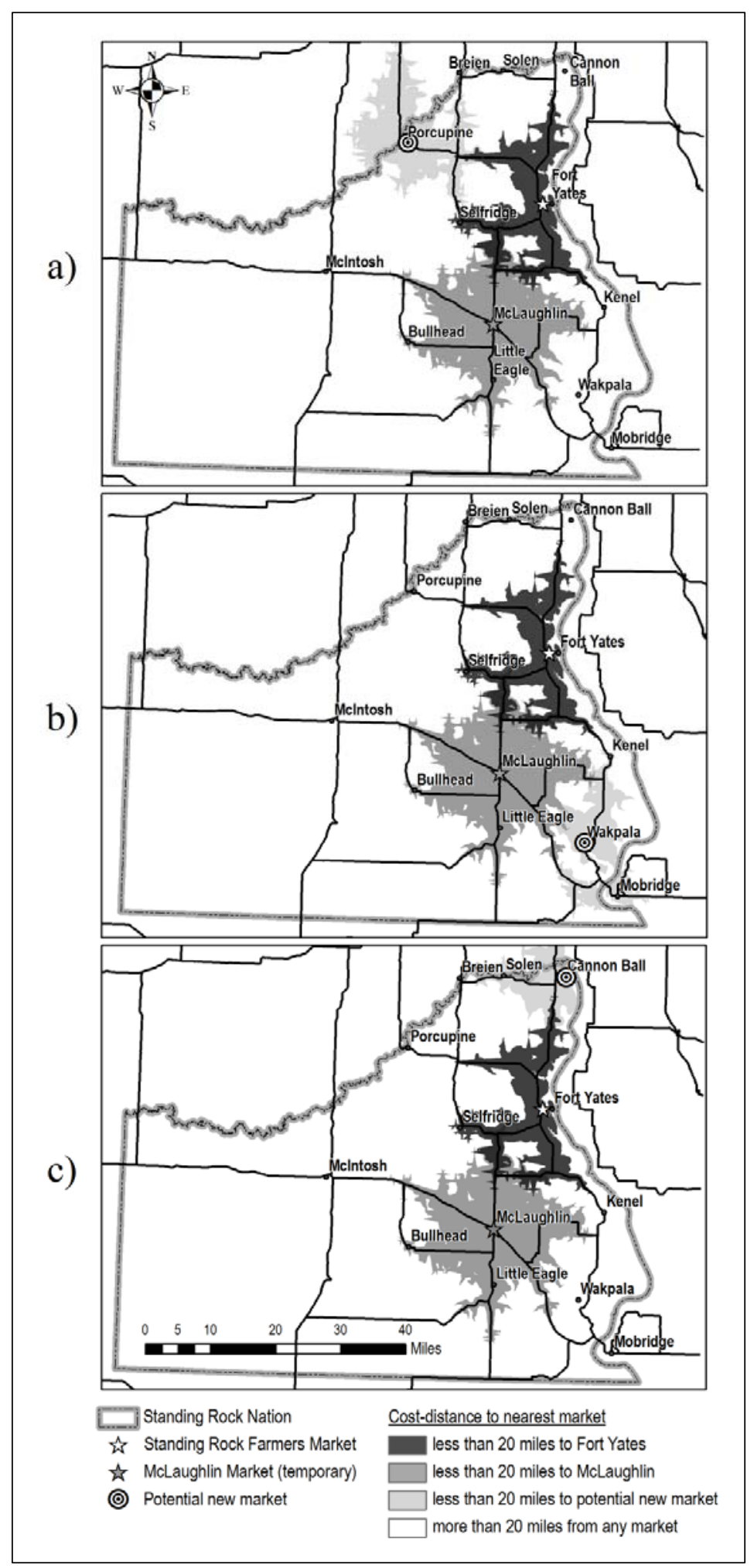


Figure 7. The Effect of Market Placement on Number of Vendors

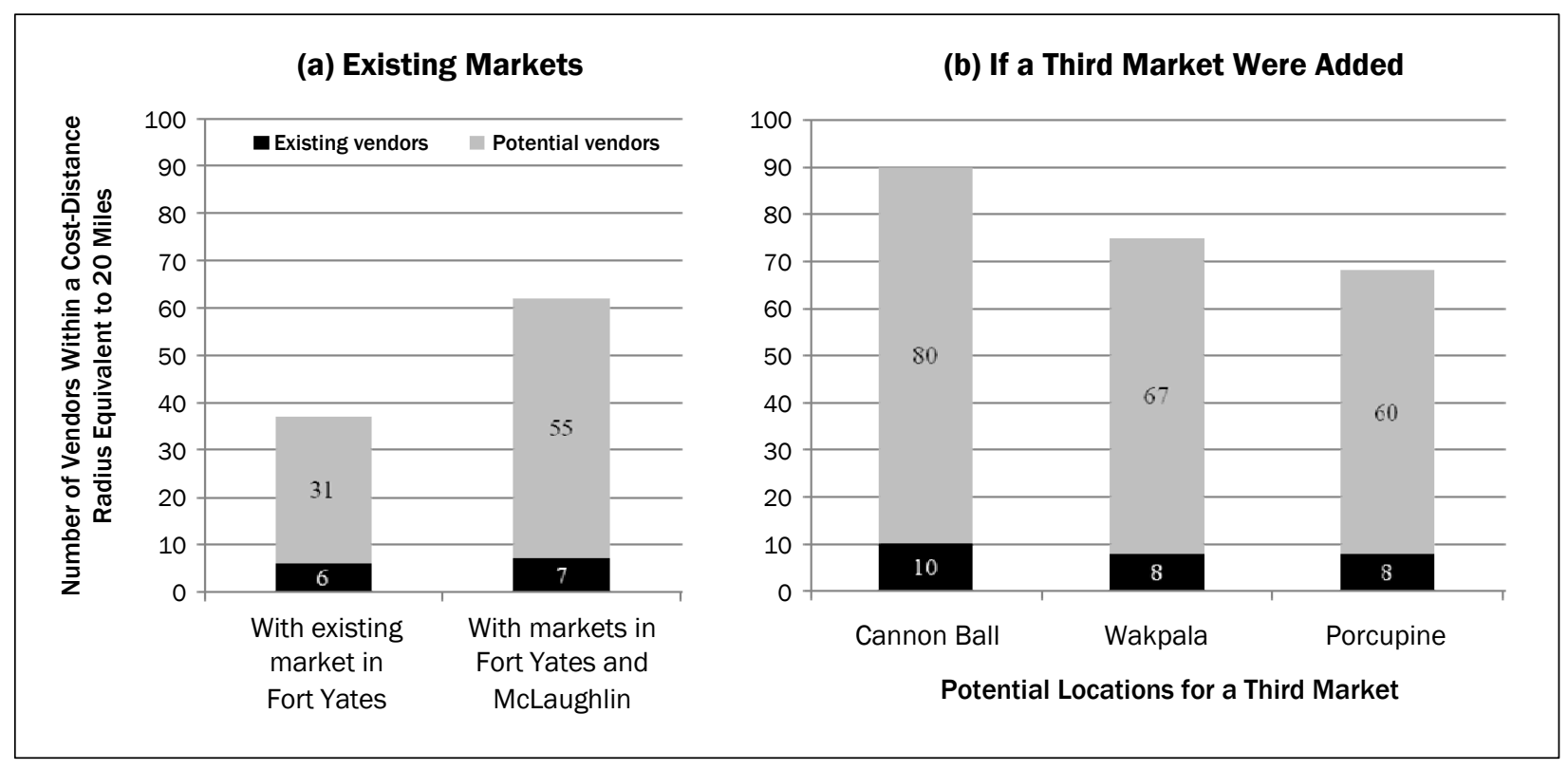

(A) If the existing market in McLaughlin is made permanent, the number of potential vendors within a costdistance radius of 20 would increase substantially. (B) A market in Cannon Ball would yield the greatest increase if a single third market were added.

potential vendors (NGP participants) live within a cost-distance radius of 20 miles from the market in Fort Yates (see figure 7). The number of authorized vendors living within that radius increases by only 1 with the addition of the McLaughlin market, but the number of potential vendors increases by $68 \%$. From the same standpoint, a new third market in Cannon Ball would have the highest number of authorized and potential vendors within a cost-distance radius of 20 miles.

\section{Discussion}

In 2009, voucher redemption rates were highly variable between districts, and we believe that part of this variability can be explained by differences in the effort required to travel to a market. New markets in districts with low redemption rates are expected to increase redemption in those districts and improve food system equity. Indeed, empirical evidence confirms this prediction: the temporary market in McLaughlin accounted for most of the voucher redemptions by elders living in Bear Soldier District (almost 75\%). Following this logic, Porcupine community is an appropriate location for a third market because Porcupine district had the lowest voucher redemption rate $(29 \%)$ in 2009.

Although locating markets in the districts with the lowest redemption rates may address program inequities by locating new markets in the most remote communities, some of these improvements have an effect on only a small number of elders.

An alternative approach is to assess the distribution of eligible participants and the spatial relationships between new markets and other communities in order to reduce the average distance and difficulty of travel for all SFMNP participants. For example, the temporary market in McLaughlin reduced the minimum cost-distance to market for six communities and therefore cut the average cost of travel for everyone in half. Based on this approach, we predict that a third market in Wakpala or Cannon Ball would result in the greatest increase in voucher redemption rates due to reductions in cost-distance to market for the most SFMNP participants. Wakpala has the third largest population of elders and one of the highest cost-distances to a market, and a new market in Wakpala would reduce travel 
costs for Kenel and Mobridge elders as well as Wakpala residents. Similarly, Cannon Ball has the same number of elders as Wakpala and a high minimum cost-distance to market. A market in Cannon Ball would also reduce the minimum costdistances from the remote communities of Solen and Breien. It is important to reiterate that neither market location would reduce the minimum costdistance to market from Porcupine District, so an additional strategy is warranted to serve that community.

In addition to improving food system access for elders, NFE and its partners also aim to increase opportunities for gardeners and gatherers, so new markets locations need to take the spatial distribution of vendors into account. Cost-distance analysis for vendors indicates that the market in Fort Yates benefited from a large number of authorized and potential vendors within a 20 -mile cost-distance radius. A permanent market in McLaughlin would require participation by new vendors, because only one previously authorized vendor lives within the designated radius. As for a third market, Cannon Ball community shows the greatest number of authorized and potential vendors living within a 20-mile cost-distance radius. An important caveat is that this analysis does not include gatherers because potential vendors were identified through their participation in gardening projects.

We have focused on readily measureable factors so that NFE, local organizational partners, and community members can interpret and utilize this research. Furthermore, the measures we have considered can be monitored within an adaptive approach to food system development. For example, we have based much of our analysis on the assumption that a permanent market is established in McLaughlin. Unforeseen circumstances may make this not feasible, and cost-distances would need to be recalculated following the addition of other markets. To that end, local organizations now have the analytical tools necessary to do so. In any case, the spatial arrangement of markets will have a bearing on the growth of the food system and sovereignty in Standing Rock.
The findings shared here should not be interpreted as specific recommendations, but rather as a set of tools and examples that can be applied now or in the future to inform decisions about new market locations. The analyses of redemption rates and minimum cost-distances are a few of multiple approaches that might anticipate the spatial concerns of organizations administering an SFMNP or similar program. We provide evidence that a permanent farmers' market in McLaughlin would succeed in increasing SFMNP voucher redemption rates, both within Bear Soldier District and reservation-wide, by reducing minimum cost-distances to market for a significant number of people in several communities. An important caveat to this finding is the low number of previously authorized vendors living in close proximity to McLaughlin; local organizations need to promote the McLaughlin market among potential vendors living in Bear Soldier and proximate districts. A third market in Porcupine would address the lowest SFMNP voucher redemption rates and the highest minimum cost-distances from a community to a market. If the goal is to reduce the minimum costdistance for the most program participants (and therefore increase redemption rates reservationwide) our analysis indicates the greatest benefits would come from a third market in either Wakpala or Cannon Ball. If markets are located based on the number of vendors available to participate, Cannon Ball has the greatest number of authorized and potential vendors within a specific costdistance radius of the community. Because the latter analysis is limited to gardeners, further research is necessary to assess the spatial distribution of gatherers, as well as the plants and animals upon which they rely.

Although distance and difficulty of travel clearly impact food-system equity, it is important to consider other factors that may affect voucher redemption. For example, in the community of Little Eagle (Running Antelope District), two elders promoted the SFMNP and ensured that other elders in their community were aware of market days and program benefits. In a relatively small community, the actions of two motivated individuals likely contributed to what were the highest par- 
ticipation and redemption rates in the Standing Rock SFMNP. In addition to community awareness and leadership, other differences between districts might affect participation and redemption rates, including the percent of people commuting to market sites to engage in other activities; access to district-owned vehicles that can transport groups of elders to markets; or the existing availability of garden produce from generous neighbors. Differences between markets also affects participation, particularly the diversity, quality, and quantity of produce available. The abundance of culturally valuable plants garnered consistent attendance at the farmers' market in Fort Yates.

We have not identified all the options to address the issues revealed here; innovative solutions may involve rotating market sites, subsidizing transportation to existing markets, or increasing the number of roadside stands in certain communities. These approaches should be considered as complementary strategies. In addition, we have not accounted for an increase in market participation by other community members (not voucher recipients) in response to new market placement. By a conservative estimate, SFMNP voucher exchanges accounted for at least $75 \%$ of sales at the markets in Fort Yates and McLaughlin. While this ensures the significance of our analysis, the federal funding that currently supports the voucher program could be reduced or withdrawn, in which case the current system might falter. Reliance on federal grants is not a reliable long-term strategy, but the influx of federal dollars has promoted rapid development of the technical skills and social-ecological infrastructures necessary for a food system that may sustain itself.

Food sovereignty is the inherent right, enduring capacity, and ecological possibility of individuals, communities, or nations to choose the food systems they generate and utilize. Food sovereignty as a right may not require localization of food systems, because communities may choose to draw on national or global networks for their food. But food sovereignty as a capacity requires that people know how to hunt, gather, grow, and distribute food. Industrial food systems rely on economies of scale to distribute food to dispersed populations, but localized food systems must account for higher per-unit costs associated with the spatial arrangement of food system components. Hence, individuals and organizations participating in food systems must consider spatial relationships in determining the locations of food system enterprises. In rural areas the cost of travel to a market can easily exceed the benefits of vending or purchasing goods from that market. As fuel costs rise and the distances people are able or willing to travel decline, the spatial arrangement of food systems becomes critical. In this context, GIS offers a set of analytical techniques to inform decisions about the distribution of food systems in time and space. Cost-distances are one set of spatial measures that may prove useful in anticipating the success of markets at specific locations in the landscape.

Innovative food assistance programs can contribute to food sovereignty by investing in local capacities. Within the United States, the SFMNP represents an unusual opportunity for tribal governments to expand food sovereignty in partnership with a federal agency. To a limited extent, NFE is able to assert food sovereignty within the federally regulated SFMNP by proposing the inclusion of specific plants. More importantly, NFE is able to contribute to food sovereignty by expanding opportunities for elders, gardeners, and gatherers to engage their knowledge and participate in the local food economy. In providing new opportunities and incentives, tribal agencies and their partners can invest in the ecological relations that comprise food systems: relations between gatherers and noncultivated plants, gardeners and soils, or elders and market vendors. As food moves within these relations, it connects people with each other and their landscape. Food sovereignty recommits communities to social and ecological relations and acknowledges long-term interdependence in order to achieve self-determination. Nevertheless, the physical limitations of ecological relations across space are real, and careful planning for the spatial arrangement of food system components is critical to generate sustainable systems. 


\section{Acknowledgements}

We thank the director of Standing Rock Nutrition for the Elderly and Caregiver Support, Luella Harrison, for her invaluable guidance and support. We are grateful for the advice and assistance of Aubrey Skye at the Native Gardens Project and Sue Isbell at Sioux County Cooperative Extension. We appreciate all the elders and vendors who participated in the 2009 Standing Rock Senior Farmers Market Nutrition Program, many of whom provided important insights about the program's significance. We would like to thank Timothy Fahey, Kurt Jordan, the editors, and the four anonymous reviewers for their careful attention to detail and valuable suggestions that strengthened this work. This material is based upon work supported by the National Science Foundation Graduate Research Fellowship under Grant No. DGE-0707428. Travel funds were provided by the American Indian Program at Cornell University.

\section{References}

Adriaensen, F., Chardona, J. P., De Blustc, G., Swinnend, E., Villalbad, S., Gulinckd, H., \& Matthysena, E. (2003). The application of "leastcost" modeling as a functional landscape model. Landscape and Urban Planning 64(4), 233-247. http://dx.doi.org/10.1016/S0169-2046(02)00242-6

Anderson, M. D., \& Cook, J. T. (1999). Community food security: Practice in need of theory? Agriculture and Human Values, 16(2), 141-150.

Centers for Disease Control and Prevention (CDC). (2007). National Diabetes Surveillance System. County Level Estimates of Diagnosed Diabetes. Retrieved April 6, 2010, from http://www.cdc.gov/diabetes/ statistics/index.htm

Elwood, S. A. (2002). GIS in community planning: A multidimensional analysis of empowerment. Environment and Planning A(34), 905-922.

Food and Agriculture Organization of the United Nations [FAO] Agriculture and Development Economics Division. (2006). Food Security (Policy Brief No. Issue 2). Rome: Food and Agriculture Organization of the United Nations.

Hallett IV, L. F., \& McDermott, D. (2010). Quantifying the extent and cost of food deserts in Lawrence,
Kansas, USA. Applied Geography 31(4), 1210-1215. http://dx.doi.org/10.1016/j.apgeog.2010.09.006

Jackson, M. Y. (1994). Diet, culture, and diabetes. In J. R. Joe \& R. S. Young (Eds.), Diabetes as a disease of civilization: The impact of culture change on indigenous peoples, Studies in the Social Sciences. New York: de Gruyter Mouton.

Johns, T., \& Sthapit, B. R. (2004). Biocultural diversity in the sustainability of developing-country food systems. Food and Nutrition Bulletin, 25(2), 143-155.

Kassam, K.-A. (2009). Biocultural diversity and indigenous ways of knowing: Human ecology in the Arctic. Calgary: University of Calgary Press.

Kassam, K.-A., Soaring Eagle Friendship Centre. (2001). So that our voices are heard: Forest use and changing gender roles of Dene women in Hay River, Northwest Territories. Calgary: CIDA-Shastri Partnership Programme.

Kassam, K.-A., The Wainwright Traditional Council. (2001). Passing on the knowledge: Mapping human ecology in Wainwright, Alaska. Calgary: Arctic Institute of North America.

Kassam, K-A., Karamkhudoeva, M., Ruelle, M., \& Baumflek, M. (2010). Medicinal plant use and health sovereignty: Findings from the Tajik and Afghan Pamirs. Human Ecology, 38(6): 817-829. http://dx.doi.org/10.1007/s10745-010-9356-9

Kraft, S. (1990). Recent changes in the ethnobotany of Standing Rock Indian Reservation (master's thesis). University of North Dakota, Grand Forks, North Dakota.

Kuhnlein, H. V., Erasmus, B., \& Spigelski, D. (2009). Indigenous peoples' food systems: The many dimensions of culture, diversity, and environment for nutrition and bealth. Rome: Food and Agriculture Organization of the United Nations.

Kuhnlein, H. V., \& Receveur, O. (1996). Dietary change and traditional food systems of indigenous peoples. Annual Review of Nutrition, 16(1), 417-442. http://dx.doi.org/10.1146/annurev.nu.16.070196. 002221

LaDuke, W. (1999). All our relations: Native struggles for land and life. Cambridge, Massachusetts: South End Press.

Lawson, M. L. (1994). Dammed Indians: The Pick-Sloan Plan and the Missouri River Sioux, 1944-1980. Norman, Oklahoma: University of Oklahoma Press.

Menezes, F. (2001). Food sovereignty: A vital requirement for food security in the context of globalization. Development, 44(4), 29-33. 
Standing Rock Nutrition for the Elderly and Caregiver Support (NFE). (2007). Needs assessment 2007. Fort Yates, North Dakota: Standing Rock Tribal Health Department.

Pevar, S. (2002). The rights of Indians and tribes: The authoritative ACLU guide to Indian and tribal rights (3rd ed.). Carbondale, Illinois: Southern Illinois University Press.

Pfaller, L. L. (1992). James McLaughlin: The man with an Indian heart. Richardton, North Dakota: Assumption Abbey.

Ruelle, M. L. (2011). Plants and foodways of the Standing Rock Nation: Diversity, knowledge, and sovereignty (master's thesis). Cornell University, Ithaca, New York.

Ruelle, M. L., \& Kassam, K.-A. S. (2011). Diversity of plant knowledge as an adaptive asset: A case study with Standing Rock elders. Economic Botany, 65(3), 295-307. http://dx.doi.org/10.1007/s12231-0119168-x

Shaw, D. J. (2007). World food security: A history since 1945. New York: Palgrave Macmillan.

Smith, R. A. (1981). Moon of popping trees (first edition). Lincoln, Nebraska: Bison Books.

Smits, D. D. (1994). The Frontier Army and the Destruction of the Buffalo: 1865-1883. The Western Historical Quarterly, 25(3), 313-338. http://dx.doi.org/10.2307/971110

Standing Bear, L. (1975). My people, the Sioux. Lincoln, Nebraska: University of Nebraska Press.
U.S. Census Bureau. (2009a). "Corson County, South Dakota," American Community Survey Demographic and Housing Estimates: 2005-2009. American Fact Finder. Retrieved April 5, 2011, from http://www.census.gov/acs

U.S. Census Bureau. (2009b). "Sioux County, North Dakota," American Community Survey Demographic and Housing Estimates: 2005-2009. American Fact Finder. Retrieved April 5, 2011, from http://www.census.gov/acs

Ullrich, J. (Ed.). (2008). New Lakota Dictionary: Lakhotiyapi-English, English-Lakhotiyapi \& incorporating the Dakota dialects of Yankton-Yanktonai \& Santee-Sisseton. Bloomington, Indiana: Lakota Language Consortium.

United Nations (2008). United Nations Declaration on the Rights of Indigenous Peoples. Retrieved September 16, 2010, from http://www.un.org/esa/socdev/ unpfii/documents/DRIPS en.pdf

Via Campesina. (1996). Food sovereignty: A future without hunger. Presented at the World Food Summit, Rome. Retrieved from http://www.voiceoftheturtle.org/library/1996\%20 Declaration $\% 20$ of $\% 20$ Food $\% 20$ Sovereignty.pdf

Windfuhr, M., \& Jonsén, J. (2005). Food Sovereignty: Towards democracy in localized food systems. Rugby, Warwickshire, UK: Intermediate Technology Development Group Ltd. 